\title{
A simple method for short-term storage and transportation of spermatophores of Pacific white shrimp (Litopenaeus vannamei)
}

\section{Método sencillo para el almacenamiento y transporte de espermatóforos del camarón blanco del Pacífico (Litopenaeus vannamei)}

\author{
Karina Morales-Ueno ${ }^{1}$, Carmen G. Paniagua-Chávez ${ }^{1}$, Alfonso Martínez-Ortega², Héctor Castillo-Juárez ${ }^{3}$ and Jorge Alfaro-Montoya ${ }^{4}$ \\ 'Department of Aquaculture, Centro de Investigación Científica y de Educación Superior de Ensenada, B.C. (CICESE), carretera Ensenada-Tijuana No. 3918 zona playitas \\ 22860, Ensenada B.C. México \\ ${ }^{2}$ Maricultura del Pacífico, S.A. de C.V. Avenida Dr. Carlos Canseco 5994 - 2do. Piso. El Cid, Marina Mazatlán. Mazatlán, Sinaloa. México \\ 3Departamento de Producción Agrícola y Animal, Universidad Autónoma Metropolitana, Xochimilco, México D.F. Calzada del Hueso 1100, Col. Villa Quietud, Delegación \\ Coyoacán, C.P. 04960, CDMX. México \\ ${ }^{4}$ Estación de Biología Marina, Escuela de Ciencias Biológicas, Universidad Nacional, Puntarenas, Costa Rica. 100 m Sur de la Gasolinera Shell, Puntarenas, Costa Rica \\ e-mail: cpaniagu@cicese.mx
}

Morales-Ueno K., C. G. Paniagua-Chávez , A. Martínez-Ortega, H. Castillo-Juárez and J. Alfaro-Montoya. 2016. A simple method for short-term storage and transportation of spermatophores of Pacific White shrimp (Litopenaeus vannamei). Hidrobiológica 26 (1): 9-14.

\begin{abstract}
The development of a shipping method for spermatophores of the white shrimp Litopenaeus vannamei would open new opportunities for sharing and improving genetic resources of shrimp worldwide. Seventy spermatophores were collected daily for 5 days (a total of 350 spermatophores from 175 shrimp), packed in microcentrifuge tubes containing $100 \mu \mathrm{L}$ of an extender solution, and placed in a Styrofoam box supplied with a thermal insulating layer and refrigerant pack to keep the samples cooled at $\sim 14^{\circ} \mathrm{C}$. Shipment of samples took $\sim 26$ hours. At arrival, spermatophores were randomly sampled either as soon as the box arrived ( 27 h, Group A) or five hours later ( $32 \mathrm{~h}$, Group B) to assess sperm viability. Spermatozoal morphology was evaluated by microscopy (100 cells per shrimp). Cells without spikes or irregular in shape were recorded as abnormal; otherwise cell morphology was recorded as normal. Spermatozoal viability was assessed by flow cytometry, whereby three populations were identified: (1) cells with intact cytoplasmatic membrane (viable), (2) cells with disrupted membrane (nonviable), and (3) cells in transition, changing from intact to disrupted membrane (transitional). Significant differences were found in spermatozoal morphology between group $\mathrm{A}$ and $\mathrm{B}(p=0.002)$, with the highest percentage of normal spermatozoa $(92 \pm 15 \%)$ found in Group A. No significant differences were found in viable $(p=0.723)$ and transitional spermatophore populations $(p=0.595)$ assessed by flow cytometry. Non-viable populations increased with time in storage $(p=0.039)$. The highest percentage of non-viable cells $(81 \pm 7 \%)$ was obtained in Group B. These results indicate that spermatophores can be cooled and transported to distant locations maintaining normal morphology and viability. These indirect quality indicators suggest that spermatozoa may be used for different purposes, including artificial insemination.
\end{abstract}

Key words: Litopenaeus vannamei, shrimp, spermatophores, transport.

\section{RESUMEN}

El desarrollo de una metodología sencilla para la movilización de espermatóforos de Litopenaeus vannamei abriría una nueva gama de oportunidades para la comercialización e intercambio de material genético a nivel mundial. Setenta espermatóforos fueron recolectados diariamente por 5 días, introducidos en tubos de microcentrífuga conteniendo $100 \mu \mathrm{L}$ de solución extensora y colocados en una caja de poliestireno acondicionada para mantener las muestras a $\sim 14^{\circ} \mathrm{C}$. Las muestras fueron trasportadas por $\sim 26$ horas y tras su arribo los espermatóforos fueron seleccionados al azar inmediatamente a su llegada ( 27 h, Grupo A) o cinco horas después ( $\sim 32$ h Grupo B) para evaluar su viabilidad. La morfología de los espermatozoides (100 células por organismo) fue evaluada microscópicamente y clasificada como normales y anormales (cuerpo irregular o sin espina). La viabilidad fue analizada por citometría de flujo, encontrando tres poblaciones: (1) espermatozoides con membrana citoplásmica intacta (viables), (2) espermatozoides con membrana comprometida (no viables) y (3) gametos en transición, iniciando cambios degenerativos en la membrana. Se encontraron diferencias significativas entre la morfología de los espermatóforos revisados a las $\sim 27$ horas (Grupo A) y cinco horas después (Grupo B) $(p=0.002)$. El grupo A tuvo el mayor porcentaje de espermatozoides normales $(92 \pm 15 \%)$. No se encontraron diferencias significativas entre los espermatóforos viables $(p=0.723)$ y en transición $(p=0.595)$ entre los grupo $\mathrm{A}$ y $\mathrm{B}$ evaluados por citometría. La población de espermatóforos no viables incrementó con el paso del tiempo $(p=0.039)$. El mayor porcentaje de espermatóforos no viables $(81 \pm 7 \%)$ se encontró en el Grupo B. Estos resultados indican que los espermatóforos pueden ser transportados a lugares distantes manteniendo su viabilidad y una morfología normal. Estos indicadores indirectos de calidad sugieren que los espermatozoides pueden ser utilizados para diferentes propósitos incluyendo la inseminación artificial.

Palabras clave: Camarón, espermatóforos, Litopenaeus vannamei, transporte. 


\section{INTRODUCTION}

The use of reproductive technologies in economically-important species has proven to have a positive impact on the management of genetic resources (Mara et al., 2013; Mylonas et al., 2010). Thus, the development and implementation of reproductive supporting methods have resulted in production improvement. Shipment of cooled semen is the method of choice in animal breeding and is not quarantined for some farm animals, like stallion and boar (Morrell, 2011). Genetic improvement of many livestock animals depends on sperm trading, which has become the standard method to achieve advanced production (Gollin et al., 2009). Trade of semen is much larger than trade of living animals because spermatozoa samples are easier to transport (FA0, 2007). Also, most reproductive management practices for farm animals use artificial insemination due to benefits such as disease control, availability of genetics lines, inbreeding control, and opportunity of gamete exchange worldwide (Foote, 2002; Morrel, 2011).

Pacific white shrimp, Litopenaeus vannamei (Boone, 1931), represents the most successful cultured marine crustacean species in the world (Benzie, 2009). It is cultured in 33 countries and, for the last five years, its production was $50 \%$ of the total world crustacean production (FA0, 2012). Despite the worldwide economic contribution of this species, the use of reproductive technologies to enhance production is scarce (Dong et al., 2004; Nimrat et al., 2006; Ulate \& Alfaro-Montoya, 2010; Morales-Ueno et al., 2013). The design of a transportation method for spermatophores would help to disseminate valuable genetic material to enhance production. It can also simplify farm reproductive practices like artificial insemination by previous collection and screening of broodstock candidates, and enable the use of spermatophores collected from valuable live, moribund or even dead organisms, having a favorable impact in the shrimp industry. Thus, the aim of this study was to test a novel shipping method for $L$. vannamei spermatophores.

\section{MATERIALS AND METHODS}

Sexually mature $L$. vannamei males were obtained from July to September 2013 from Maricultura del Pacífico, a Mexican shrimp hatchery. Males were placed separately into maturation tanks $(5 \times 9 \times 1.20 \mathrm{~m})$ at a density of eight shrimp per $\mathrm{m}^{2}$ and water column of $0.35 \mathrm{~m}$. Temperature was kept at $28 \pm 1^{\circ} \mathrm{C}, 34 \mathrm{~g} / \mathrm{L}$ salinity, dissolved oxygen at $\sim 4 \mathrm{mg} / \mathrm{L}$ and $300 \%$ water exchange rate per day using sand biofilters. The shrimp were fed at $5 \%$ tank biomass every 4 hours with pellets (35 $-40 \%$ protein), squid, polychaetes, krill, and paprika.

Seventy spermatophores were manually collected and transported every day for 5 days. A total of 350 spermatophores from 175 randomlychosen mature males were collected after five days of experimentation. Individual spermatophores were randomly placed on a small piece of food-grade wax paper, gently wrapped, and placed in separated 1.8-mL microcentrifuge tubes (70 tubes per day) containing $100 \mu \mathrm{L}$ of an extender solution $\left(2.125 \mathrm{~g} \mathrm{NaCl}, 0.110 \mathrm{~g} \mathrm{KCl}, 0.052 \mathrm{~g} \mathrm{H}_{3} \mathrm{BO}_{3}, 0.019 \mathrm{~g} \mathrm{NaOH}\right.$, $0.484 \mathrm{~g} \mathrm{MgSO}_{4} 7 \mathrm{H}_{2} \mathrm{O}, 20 \mu \mathrm{L}$ of antibiotic/antimycotic SIGMA A7292, in $100 \mathrm{~mL}$ of distilled water) (Morales-Ueno et al., 2013) to keep moisture inside the tube. Extender solution was adjusted to $\sim 800 \mathrm{m0smol} / \mathrm{kg}$ (Vapro 5520, Wescor Inc. UT, USA) and pH 7.4.

The tubes were individually inserted in a Styrofoam rack and tightly covered with plastic wrap. Then the rack was placed into a Styrofoam box (external measurements $18.3 \times 23.7 \times 29 \mathrm{~cm}, 2 \mathrm{~cm}$ thickness, and $2.9 \mathrm{~L}$ internal capacity) between a Styrofoam thermal insulating layer and 1800-g Koolit $®$ frozen gel pack pouches (Cold Chain Technologies, MA, USA). This arrangement kept the internal temperature of the tubes at approximately $14^{\circ} \mathrm{C}$ for $\sim 32 \mathrm{~h}$ (Fig. 1). Assessment of the tubes internal temperature was performed before and after transportation using type K thermocouples (Cole-Parmer, IL, USA) and a handheld Digi-Sense Dual JTEK thermocouple thermometer (Cole-Parmer, IL, USA).

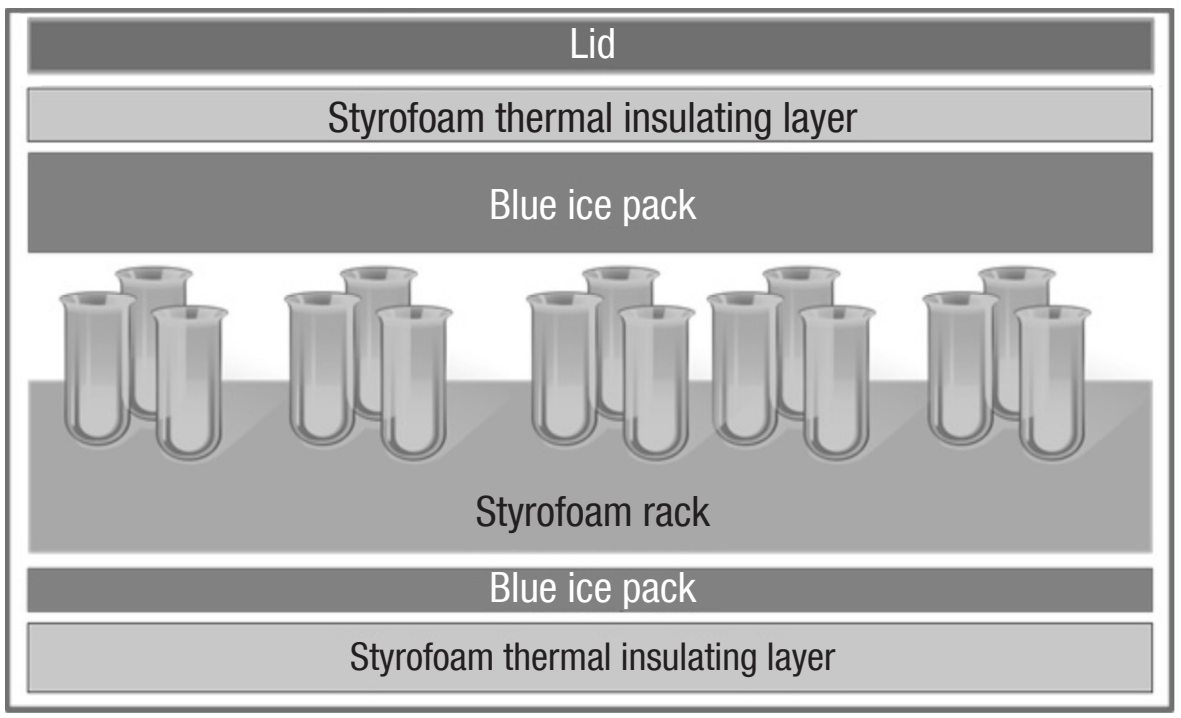

Figure 1. Representation of a Styrofoam box containing spermatophore samples maintained at approximately $14{ }^{\circ} \mathrm{C}$ and transported to the National Subsystem for Aquatic Genetic Resources in Ensenada, Baja California, Mexico. 
Once the box was filled and closed, it was delivered overnight by a conventional delivery service from the hatchery, located in Los Pozos, Sinaloa, Mexico (22 $\left.59^{\prime} 4.25^{\prime \prime}, 106^{\circ} 9^{\prime} 46.28^{\prime \prime}\right)$, to the National Subsystem for Aquatic Genetic Resources at CICESE in Ensenada, Baja California, Mexico (31 $52^{\prime} 3.12^{\prime \prime N}-116^{\circ} 39^{\prime} 54.07^{\prime \prime}$ W). Samples traveled by airplane for $\sim 23 \mathrm{~h}$, with three connecting points and by land from Tijuana to Ensenada, Baja California (total transportation distance of $\sim 3,600 \mathrm{~km}$ ). Five shipments were sent for this experiment.

Once the boxes were received, the frozen gel pack pouches were replaced to maintain the temperature at $\sim 14^{\circ} \mathrm{C}$, and a total of 12 tubes were randomly collected at two time intervals: six tubes as soon as the box arrived ( 27 hours, Group A) and six additional tubes five hours later ( 32 hours, Group B). The rest of the 58 tubes were used to evaluate pathogen transfer in samples. The sperm mass was collected by pressing the posterior region of the spermatophore until the sperm mass droplet was formed outside the wing structure. Each sperm mass was suspended in $980 \mu \mathrm{L}$ of extender solution and an aliquot $(100 \mu \mathrm{L})$ was re-suspended into $900 \mu \mathrm{L}$ of extender to determine sperm viability.

Light microscopy analysis. Spermatozoal morphology observations were based on previous reports that established that primary binding between vitelline envelopes and spermatozoa spikes is a prerequisite for fertilization (Rojas \& Alfaro, 2007; Ulate \& Alfaro-Montoya, 2010). For this assay, $20 \mu \mathrm{L}$ of the re-suspended sample were placed on a slide, covered with a cover glass and examined using a microscope (Olympus CX31) at $400 \mathrm{X}$ magnification. One hundred spermatozoa in at least five fields of view were observed using the phase-contrast mode. Spermatozoa with bent, missing spikes or malformed bodies were recorded as abnormal, whereas those with complete spikes and spherical bodies were assessed as normal (Fig. 2).

Observations were performed within 3 minutes of smear preparation and to ensure a high repeatability, the same microscopist performed all the estimations.

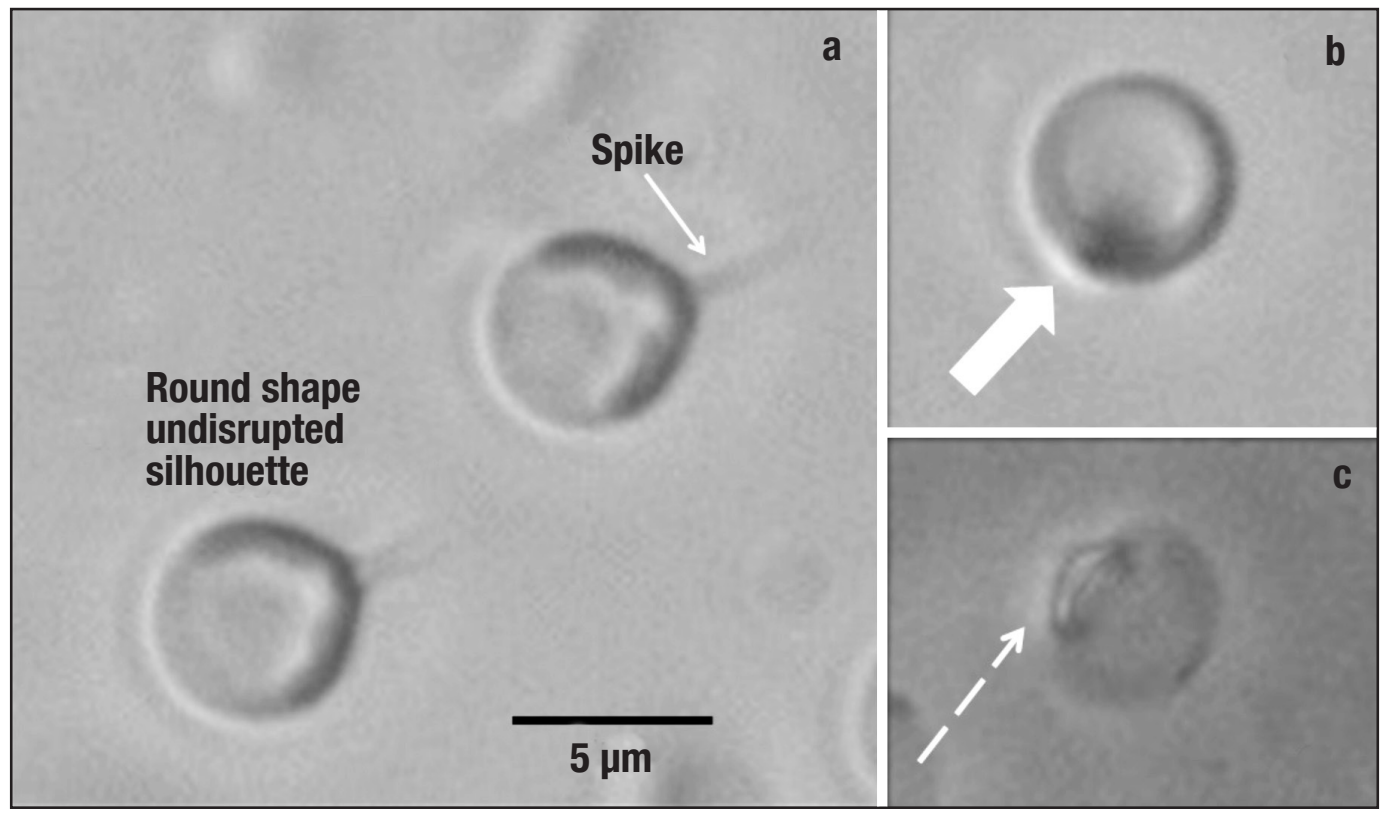

Figures 2a-c. Spermatozoa imaged by phase-contrast microscopy at 1000X magnification: a) Normal spermatozoa showing morphological integrity [a], notice the round complete shape and spike attached. b) Normal spermatozoan diameter of $\sim 5 \mu \mathrm{m}$. Abnormal spermatozoa: without spike (solid arrow). c) Abnormal spermatozoa with irregular shaped silhouette (dotted arrows).

Flow cytometry analysis. Spermatozoal viability from each male, in terms of membrane integrity, was assessed by flow cytometry according to the methodology suggested by Lezcano et al. (2004). This analysis was performed using an Attune flow cytometer (Attune ${ }^{\circledR}$ Acoustic Focusing Cytometer, Applied Biosystems, Carlsbad, CA, USA), equipped with blue and violet lasers (488 nm [20mW] and $405 \mathrm{~nm}$ [50mW]). Forward and side light-scatter data were collected in linear mode and fluorescence data were collected in logarithmic mode. Samples were stained with the LIVE/DEAD ${ }^{\circledR}$ Sperm Viability Kit (Life Technologies, Eugene, OR, USA). Briefly, individual sperm masses were suspended in 1 $\mathrm{mL}$ extender solution, having been first stained with $5 \mu \mathrm{L}$ of the working solution of SYBR-14 (100 nM final concentration) and incubated for 10 min in the dark. Then, $5 \mu \mathrm{L}$ of Propidium lodide (PI) stock solution (12 $\mu \mathrm{M}$ final concentration) was added and the sample was incubated for another $10 \mathrm{~min}$. During stain incubation, samples were kept at $14^{\circ} \mathrm{C}$. Membrane integrity was detected with the green fluorescent dye (SYBR 14), and membrane-damaged cells with the red fluorescent dye propidium iodide (PI). Fluorescence of SYBR 14 was detected by the BL1 detector using a 530/30 center bandpass filter and PI fluorescence was detected by the BL3 detector using a 640-nm longpass filter. Data were collected from 10,000 events. Flow cytometry was performed at room temperature $\left(23^{\circ} \mathrm{C}\right)$. Flow cytometry analysis generated percentage data for three spermatozoa populations based on their membrane integrity: (1) cells containing intact cytoplasmatic membrane were conside- 
red viable, (2) cells containing disrupted cytoplasmatic membrane were considered non-viable, and (3) transitional, defined as cells changing from intact cytoplasmatic membrane to disrupted cytoplasmic membrane.

Data analysis. Statistical analysis was performed using NCSS 9 software (NCSS, Kaysville, Utah, USA). A linear mixed model was used to analyze "morphology" and flow cytometry data. Two-way analysis of variance was used to test the effect of sample transportation for $~ 27$ and $\sim 32 \mathrm{~h}$ (groups A and B) and the effect of day of transportation (5 different days). Data were arcsine square-root transformed before analysis. Specific differences among treatment groups were identified by the Tukey test. A value of $P<0.05$ was chosen as the level for significance.

\section{RESULTS}

Significant differences were found in spermatozoal morphology between group $\mathrm{A}$ and $\mathrm{B}(p=0.002)$, with the highest percentage of normal spermatozoa $(92 \pm 15 \%)$ found in Group A (i. e., these cells maintained their appropriate structure necessary for spermatozoa-eggs interaction required for fertilization), whereas the normal spermatozoa percentage decreased (56 $\pm 18 \%$ ) in Group B ( $32 \mathrm{~h}$ ). Spermatozoal morphology was not affected ( $p=0.514$ ) by day of transportation (5 different days). The average of the inner temperature before shipping was $14.7^{\circ} \mathrm{C}$ and the average at its arrival was of $17.4^{\circ} \mathrm{C}$. Temperatures between Group $\mathrm{A}$ and $B$ do not show any significant differences $(p=0.832)$.

No significant differences were found between groups $A$ and $B$ in viable $(p=0.723)$ and transitional spermatophore populations $(p=$ $0.595)$ assessed by flow cytometry. However, the day of transportation affected viable $(p=0.021)$ and transitional populations $(p=0.004)$. Non-viable populations increased with time in storage $(p=0.039)$. The highest percentage of non-viable cells $(81 \pm 7 \%)$ was obtained in Group B. (Fig. 3).

\section{DISCUSSION}

In this experiment, the assessment of spermatozoa quality was performed using two different approaches: the identification of accurate morphology that indicates that the cells maintain their structure and shape to perform normal interaction with eggs, and the identification of cytoplasmatic membrane integrity using probes, which indicates that if this structure is compromised, this could lead to cell death. According to the microscopic observations, a high percentage of cells $(92 \%)$ in Group A maintained their morphological integrity. However, after $\sim 32 \mathrm{~h}$ of collection, the viability of cells decreased rapidly, showing that shrimp sperm is very fragile and cannot be stored for a long time at $14^{\circ} \mathrm{C}$. No significant differences were found between the days of transportation, indicating that sampling, packing, and transportation during the 5 different days was standardized.

Compared to other studies on $L$. vannamei spermatophores, which showed variable percentages of abnormal spermatozoa in the wild $(38 \%)$ and in reproduction hatchery facilities $(25.5-74 \%)$ (AlfaroMontoya, 2010), our results showed low abnormal spermatozoa ( 8\%), indicating they were not affected by their transportation. However, this percentage is not reflected in flow cytometry data. This is due to the fact that flow cytometry detects different traits related to the general condition of the spermatozoa based on cytoplasmatic membrane inte- grity, which cannot be assessed by microscopic examination. For example, the transitional population may not show evident morphological changes detected by microscopy. However, this population, observed by flow cytometry, showed that spermatozoa were changing from intact to disrupted cells. This finding suggests that cells in a transitional stage could maintain their morphological structure. Nevertheless, it is unknown if they keep, or do not keep, their fertilizing potential. A previous study by Morales-Ueno et al. (2013) reported successful insemination of females with sperm kept for $4 \mathrm{~h}$, in the same conditions reported in this paper. Therefore, further studies will be important to evaluate the fertilization capability of sperm transported for $\sim 27 \mathrm{~h}$.

The term "sperm viability" is widely used and usually linked to an intact cytoplasmatic membrane, since membrane integrity is essential for the gamete to perform effective interactions with the oocyte and maintain its homeostasis. Currently, detection of cytoplasmaticmembrane integrity using dual fluorescent probes is the most useful technique to estimate the survival of cell types and the most suitable for the detection of cellular death (Hossain et al., 2011). However, this technique requires the use of expensive and specialized equipment, not always available in the hatchery. Consequently, our results showed that morphological examination can be quickly and easily achieved, and at least for group A's time frame, this measurement could give us a general indication of spermatozoan apparent viability.

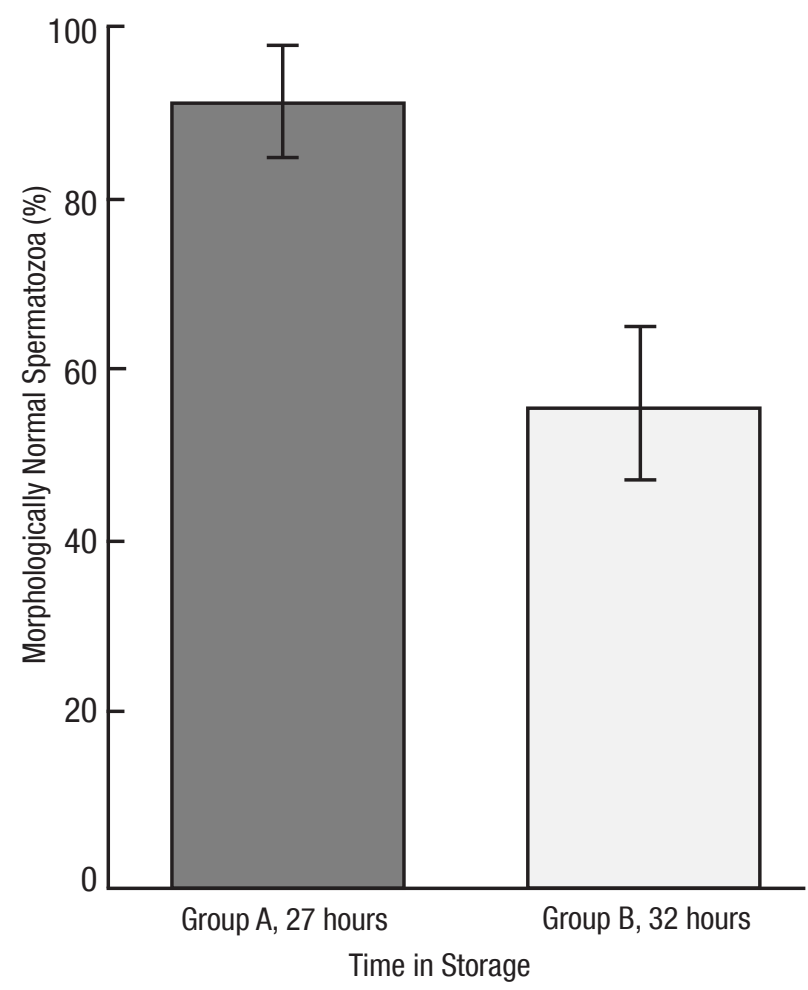

Figure 3. Cytoplasmic membrane integrity of $P$. vannamei spermatozoa assessed by flow cytometry shows a percentage increase for the "non-viable" cell population from Group A to Group B $(p=0.039)$ 
It was not possible to determine sperm density or quality of spermatophores in the hatchery before transportation. Therefore, we used the results obtained from artificial insemination as a spermatophore quality control, using males of the same population selected for this procedure. Results of artificial insemination in the farm showed that one spermatophore yielded $\sim 250,000$ nauplii per female, which indicated a good fertilization. Then, with this indirect approach, we suggest that the quality of the spermatophores used in our work was as good as the quality of the spermatophores used in the farm.

Shipment of cooled $\left(\sim 14^{\circ} \mathrm{C}\right)$ L. vannamei spermatophores represents a good alternative to avoid the membrane cell damage that occurs when samples are held between 2 and $5^{\circ} \mathrm{C}$ (in refrigeration), because these temperatures induce membrane damage (Salazar et al., 2009). Consequently, we were able to keep a high percentage of morphologically normal spermatozoa and a low percentage of non-viable sperm cells population by maintaining the samples cooled at $14^{\circ} \mathrm{C}$.

The objective of adding extender solution into the tubes was to maintain the relative humidity of the sample, avoiding desiccation and conserving adhesiveness of the spermatophores. In addition, the wax paper used to wrap each spermatophore made it easy to recover the sample from the tube and the extraction of the sperm mass from the spermatophore.

The development of a simple technique to transport cooled spermatophores would be beneficial to the shrimp industry for several reasons: (1) shipping spermatophores will be cheaper than transporting living mature organisms, (2) shipping spermatophores, instead of broodstock, avoids negative outcomes such as transportation stress and subsequent mortality threats, (3) the risk of disease transmissions can be minimized, (4) the sperm mass can be used for artificial insemination in distant places, (5) shipping spermatophores decreases the inherent hazard of moving nonindigenous species, making in general unnecessary to ask for legal transportation permissions, and (6) facilitates the possibility of collecting sperm from moribund or recently dead organisms, if necessary, as has been the case among some animals (Woodford \& Rossiter, 1993; Greer \& Harvey, 2004; Martínez-Pastor et al., 2005; Biber-Klemm \& Temmerman, 2010). The adoption of any transportation method into the routine hatchery practices of the shrimp industry has to be as simple as possible to overcome additional costs related to hiring and training specialized personnel.

Biosecurity is a key component to be considered in the transportation of spermatophores. Bacterial contamination and the possible propagation of diseases is an important issue for aquatic species (Nimrat \& Vuthiphandchai, 2008). Therefore the extender solution used in our experiments contained antibiotic/antimycotic to prevent bacterial proliferation. A protocol to maintain $L$. vannamei spermatophores at $2-4^{\circ}$ $C$ for a month was developed by Nimrat et al. (2006). Mineral oil with $0.1 \%$ penicillin-streptomycin was used to prevent bacterial proliferation and apparent sperm viability was recorded using eosin-nigrosin staining. Although this protocol was a good method to prevent bacterial proliferation and enhance spermatophores viability, we found that the addition of mineral oil to the spermatophore caused a loss of sperm mass adhesive proprieties, which are critical for artificial insemination. The extender solution and the transportation protocol used in our study were a good method to keep sperm mass characteristics essential for artificial insemination and transportation of spermatophores to distant places. Nevertheless, bacterial dissemination in transported samples is still a concern. Research on the type of bacteria found in cryopreserved sperm mass samples was performed indicating the possibility of preserving pathogenic or beneficial bacteria (Morales-Ueno et al., 2015). In conclusion, transportation time is a critical element to be considered, since samples transported for $>27 \mathrm{~h}$ decrease viability and a bacteriological analysis for transported samples is required as a sanitary protocol to prevent possible dispersion of pathogen bacterial.

\section{ACKNOWLEDGEMENTS}

This research funding was provided by SAGARPA project No. RGABC-12-00002. We thank CONACyT for providing a doctoral scholarship for the first author. We also thank the crew at Maricultura del Pacífico, S.A. de C.V. for technical assistance, particularly Juan Carlos Quintana and Cesáreo Cabrera.

\section{REFERENCES}

Alfaro-Montoya, J. 2010. The reproductive conditions of male shrimps, genus Penaeus, sub-genus Litopenaeus (open thelyca penaeoid shrimps): A review. Aquaculture 300: 1-9.

BENZIE, J. A. H. 2009. Use and exchange of genetic resources of penaeid shrimps for food and aquaculture. Reviews in Aquaculture 1: 232250.

Biber-Klemm, S. \& M. Temmerman. 2010. Rights to Animal Genetic Resources for Food and Agriculture. In: Access and Benefit Sharing (Eds.). Swiss National Centres of Competence in Research. Switzerland, pp. 1-19.

Boone, L. 1931. Anomuran, macruran Crustacea from Panama and Canal Zone. Bulletin of the American Museum of Natural History 63:137189.

Dong, Q. X., J. D. Lin, \& C. J. Huang. 2004. Effects of cryoprotectant toxicity on the embryos and larvae of pacific white shrimp Litopenaeus vannamei. Aquaculture 242: 655-670.

FA0 (Food and Agriculture Organization). 2007. Flows of animal genetic resources. In: The State of the World's Animal Genetic Resources for Food and Agriculture. Edited by Rischkowsky, B. \& Pilling. In: Flows of animal genetic resources, D. FAO (Food and Agriculture Organization), Rome. pp. 51-76.

FA0 (Food and Agriculture Organization). 2012. World Review of Fisheries and Aquaculture - Status and trends. In: The State of World Fisheries and Aquaculture 2012. Ed. by FAO (Food and Agriculture Organization). Fisheries and Aquaculture Department, Rome, Italy. pp. 3-106.

Fo0te, R. H. 2002. The history of artificial insemination: Selected notes and notables. Journal of Animal Science 80:1-10.

Golıin, D., E. Van Dusen, \& H. Blackburn. 2009. Animal genetic resource trade flows: Economic assessment. Livestock Science 120: 248255. 
Greer, D. \& B. HARvey. 2004. The gene rush: Finding new value in aquatic biodiversity. In: Greer, D. (Eds.). Blue Genes: Sharing and Conserving the World's Aquatic Biodiversity. Earthscan. Ottawa, Canada, pp. 23-60.

Hossain, M., A. Johannisson, M. Wallgren, S. Nagy, A. Siqueira, \& H. RodriguezMaRTINEZ. 2011. Flow cytometry for the assessment of animal sperm integrity and functionality: state of the art. Asian Journal of Andrology 13: 406-419.

Lezcano, M., C. Granja, \& M. Salazar. 2004. The use of flow cytometry in the evaluation of cell viability of cryopreserved sperm of the marine shrimp (Litopenaeus vannamei). Cryobiology 48: 349-356.

Mara, L., S. Casu, A. Carta, \& M. Dattena. 2013. Cryobanking of farm animal gametes and embryos as a means of conserving livestock genetics. Animal Reproduction Science 138: 25-38.

Martínez-Pastor, F., C. Guerra, M. Kaabi, A.R. Díaz, E. Anel, P. Herraez, P. de Paz, \& L. ANEL. 2005. Decay of sperm obtained from epididymes of wild ruminants depending on postmortem time. Theriogenology 63: 24-40.

Morales-Ueno, K., H. H. Montaldo, A. M. Ortega, C. G. Paniagua-Chávez \& H. CASTILLO-JuÁrez. 2013. An extender solution for the short-term storage of Litopenaeus vannamei sperm to be used in artificial insemination. Aquaculture Research 44: 1254-1258.

Morales-Ueno K., C. G. Paniagua-Chávez, R. Vasquez-Yeomans, J. A. CáceresMartínez \& M. A. del Rio-PoRTILla. 2015. Bacteria in cryopreserved sperm mass of the White shrimp Penaeus vannamei. Cryoletters 36(6):372-378.

Morrell, J. M. \& M. Wallgren. 2011. Colloid centrifugation of boar semen. Reproduction in domestic animals. Zuchthygiene 46(2):18-22.
MyLonas, C. C., A. Fostier \& S. Zanuy. 2010. Broodstock management and hormonal manipulations of fish reproduction. General and Comparative Endocrinology 165: 516-534.

Nimrat, S., S. Siriboonlamom, S. Zhang, Y. Xu, \& V. Vuthiphandchai. 2006. Chilled storage of white shrimp (Litopenaeus vannamel) spermatophores. Aquaculture 261: 944-951.

NimRAT, S. \& V. VUTHIPHANDCHAl. 2008. Role of bacterial in the chilled storage and cryopreservation of sperm in aquatic animals: a review. In: Aquaculture Research Trends. Ed. by Schwartz S. H. Nova Science Publisher, Inc. New York, USA, pp. 149-184.

ROJAS, E. \& J. AlFARO. 2007. In vitro manipulation of egg activation in the open thelycum shrimp Litopenaeus. Aquaculture 264: 469-474.

Salazar, M., Lezcano, M. \& C. Granja. 2009. Protocol for cryopreservation of Penaeus vannamei sperm cells. In: Methods in reproductive aquaculture: marine and freshwater species. Ed. by Cabrita, E., Robles, V. \& Herráez, P. CRC Press, Boca Ratón, FL. p. 505.

Ulate, K. \& J. Alfaro-Montoya. 2010. Sperm-egg incompatibility in interspecific inseminations of Penaeus (Litopenaeus) occidentalis, $P$. (Litopenaeus) stylirostris and $P$. (Litopenaeus) vannamei. Aquaculture 309: 290-292.

Woodford, M. H. \& P. B. Rossiter. 1993. Disease risks associated with wildlife translocation projects. Revue Scientifique et Technique 12: 115-135.

Recibido: 04 agosto de 2014.

Aceptado: 31 de julio de 2015. 